\title{
Colonization potential of an endangered riparian shrub species
}

\author{
Sabine Fink ${ }^{1}$ (D) Tabea Lanz ${ }^{1} \cdot$ Rebecca Stecher $^{1}$ • \\ Christoph Scheidegger ${ }^{1}$
}

Received: 30 November 2016/Revised: 15 March 2017/Accepted: 30 March 2017/

Published online: 7 April 2017

(C) Springer Science+Business Media Dordrecht 2017

\begin{abstract}
Riparian areas and their plant communities are threatened due to human exploitation and habitat loss. Conservation of riparian vegetation requires knowledge on limiting factors in the biology of species preventing its spread along suitable areas. It needs to be assessed if an endangered species is trapped in an extinction vortex or whether it can recover from its current bottleneck situation by management measurements. We investigate the recovery potential of an endangered riparian shrub species of European rivers, the German tamarisk, Myricaria germanica, by combining field and lab experiments on seed production, germination and wind dispersal with a modelling approach on species distribution. While the seed potential is high, wind-mediated dispersal is average, with a majority of seeds falling next to the mother shrub. The modelled dispersal kernel shows highest goodness-of-fit with a polynomic function. Including this kernel in a model on the future distribution of the species based on identification of suitable habitat, limited spread to new areas in Switzerland after 20 and 50 dispersal events is predicted. Given the current limited distribution of the German tamarisk in Switzerland, conservation efforts are required to allow for the formation of new riparian habitat. Additionally, connectivity
\end{abstract}

Communicated by Daniel Sanchez Mata.

Electronic supplementary material The online version of this article (doi:10.1007/s10531-017-1347-3) contains supplementary material, which is available to authorized users.

Sabine Fink

sabine.fink@wsl.ch

Tabea Lanz

lanz.tabea@gmail.com

Rebecca Stecher

rebecca.stecher@hotmail.com

Christoph Scheidegger

christoph.scheidegger@wsl.ch

1 Swiss Federal Institute for Forest, Snow and Landscape Research, WSL, Zürcherstrasse 111, 8903 Birmensdorf, Switzerland 
along river networks has to be enhanced to help the species to escape the extinction vortex it is trapped in.

Keywords Riparia · Colonization · Floodplain · Myricaria germanica $\cdot$ Dispersal kernel $\cdot$ Species distribution model (SDM)

\section{Introduction}

Riparian areas have a high conservation priority since they consist of a mosaic of habitats with high species diversity (Sabo et al. 2005). Despite many ecosystem functions of riparian areas (e.g. buffer functions, see Sweeney and Newbold 2014), they are subject to human exploitation and degradation. Especially riparian areas of running waters are threatened, since natural river dynamics were altered for e.g. flood protection reasons, gravel excavation and for the gain of hydropower (see Lytle and Poff 2004). The resulting loss of habitat and increasing fragmentation of landscape have a major impact on specialized riparian species, especially on sessile plants (Jansson et al. 2000).

Many riparian plant species underwent a massive decrease in population distribution (e.g. see Endress 1975), and are additionally threatened by competition with invasive alien species (Catford and Jansson 2014; Richardson et al. 2007). To preserve riparian vegetation, limiting factors in the demography of species (e.g. seed production, germination and dispersal) have to be identified to avoid acceleration of population declines and ultimately species loss (Catford and Jansson 2014; McGeoch and Latombe 2016). Especially knowledge on dispersal is important as it is a key factor to colonize new habitat, e.g. created after conservation and managing efforts (Clobert et al. 2012).

While most plants are dispersed over short distances by wind (Willson 1993), riparian species can show adaptations to water-mediated dispersal (e.g. Chen and Xie 2007), although upstream dispersal by wind recently got more attention in terms of conservation efforts (Wubs et al. 2016). Still, the knowledge on dispersal vectors, distances and directions is limited, although it is crucial for the conservation of rare species (Driscoll et al. 2014; Swift and Hannon 2010). More riparian species have to be investigated to ensure habitat connectivity after habitat loss and to adjust conservation goals (Driscoll et al. 2013; Pullin et al. 2009).

Our study focuses on the German tamarisk, Myricaria germanica, a characteristic species of a typical riparian plant community along alpine European rivers (Ellenberg 2010). Genetic analyses on the German tamarisk in Switzerland suggest high gene flow within and between catchments (Werth et al. 2014), indicating historic dispersal up- and downstream of rivers. The morphology of small, pappus-bearing $M$. germanica seeds is adapted to wind-mediated dispersal, as found in previous studies (Bill et al. 1997). Nevertheless, the dispersal potential by wind has to be verified, as not all species of a pappusbearing family are equally well dispersed (for the family Asteracea, see Tackenberg 2003). For another Myricaria species, predominantly wind-, but also water-mediated dispersal has been found (Myricaria laxiflora, Chen and Xie 2007).

Despite the knowledge on historic gene flow in M. germanica in Switzerland (Werth et al. 2014), the colonization potential of this rare riparian species in Switzerland remains unclear. The species abundance and distribution decreased considerably in Switzerland over the last century (for comparative maps see Swiss data base on plant distribution, www.infoflora.ch), and is listed as vulnerable (Bornand et al. 2016). The German tamarisk survived only in few catchments (Werth et al. 2014), and drastic reductions of marginal 
populations in areas of metapopulation dynamics have been reported (Kolly 2007). Only few studies focusing on the natural factors causing the limited distribution are available (Kudrnovsky 2013; Lener 2011; Lener et al. 2013; Müller and Scharm 2001). Therefore seed production, dispersal parameters, habitat requirements as well as germination properties should be investigated to ensure long-term preservation of the species.

This study assesses, whether the German tamarisk is able to recover from its current bottleneck situation or whether it is more likely to be trapped in the extinction vortex (Gilpin and Soule 1986). As single factors resulting in species decrease are unlikely (Brook et al. 2008), we identify several factors influencing the persistence and spread of $M$. germanica populations in Switzerland: the amount of seeds produced by the shrub, the distance it is dispersed by wind and its germination ability. A classical technique to estimate dispersal in the field (Greene and Calogeropoulos 2002) is linked with a modelling approach on habitat suitability, estimated based on environmental parameters (climate, topographic and geological predictors). The simulation of dispersal from current source populations to suitable habitat allows us to answer the question whether our model species is able to spread within time spans of 20 and 50 years.

\section{Materials and methods}

\section{Field work}

Field work on seed dispersal was performed in 2009 from June to September, the peak season for flowering and seed dispersal. We investigated a core population of 22 individuals of a height of $1 \mathrm{~m}$, spread over an area of $8 \times 16 \mathrm{~m}$ along the river Sense, canton of Fribourg, Switzerland. As this population was surrounded by low vegetation, unpopulated gravel banks and water, it was ideal to measure the seed potential and the windmediated dispersal. To obtain information on age dependent seed potential, we added information on a single mature $M$. germanica shrub of a height of $2.5 \mathrm{~m}$. This individual was positioned upstream (in the South) at an independent gravel bank co-existing with tall willow shrubs (Salix ssp.).

\section{Seed potential}

To assess the seed potential of $M$. germanica, inflorescence phenology, estimates for buds per inflorescence and estimates of the seeds per capsule were used. The total count of inflorescence per shrub and the inflorescence phenology was estimated on the mature $M$. germanica shrub and 22 individuals in the core population on 5 days from June to September. The different dates were chosen to represent the total seed release time of $M$. germanica and to take into account seasonal variability. Over $50 \%$ of the phenological type had to be present to assign the counted inflorescence to either of the five categories: budding inflorescence, flowering inflorescence, closed capsule, seed producing capsule with seeds and empty capsule. To estimate the mean count of buds per inflorescence, we analyzed ten inflorescences with closed buds on 6 days from June to September. Additionally, ten closed capsules were analyzed for the number of seeds per capsule at 4 days during the same time span. To assess the seed potential per year, we multiplied the mean count of seed producing inflorescence of the date with the peak inflorescence, the mean count of buds per inflorescence, and the mean count of seeds per capsule. 
To obtain an unbiased estimate of the seed production by correcting counted seeds with germination rates, we performed a germination experiment in the lab. The seeds of five capsules of both random individuals from the core population and of the single mature $M$. germanica shrub were put on wet tissue paper to initiate germination. After $12 \mathrm{~h}$, seeds were classified as either non-germinating or germinating (seeds shortly before germination and seeds with developed germination root).

\section{Wind-mediated dispersal distance}

Seed dispersal by wind was investigated by a common trapping experiment in the field (e.g. see Müller and Scharm 2001), with subsequent fitting of the dispersal curve to mechanistic models (Bullock and Clarke 2000; Levey et al. 2002; Nathan 2001). Wind dispersal distance and direction were estimated by capture of seeds with a network of cone traps with a diameter of $0.43 \mathrm{~m}$. Eight traps each were set up directly beneath the mature shrub and within the core population. Additionally, traps were positioned at 10, 25 and $50 \mathrm{~m}$ from the core population area only with two traps at each distance and each cardinal direction (North, South, East and West). This setup could not be repeated for the mature shrub, as it was surrounded by willows. All traps were monitored during four time periods with increasing number of days for seed collection (3, 7, 9, 15 days). Direct visual observations of seed dispersal were recorded and wind speed was measured with a handheld anemometer EA-3000 (Conrad Electronic, Zürich, Switzerland). To compare wind dispersal abilities of the German tamarisk to other species, information on the terminal velocity of $M$. germanica seeds was required. Ten pappus-bearing seeds were used to assess the terminal velocity in the lab. Each seed was dropped ten times from a height of $2.58 \mathrm{~m}$ and falling time was recorded.

\section{Dispersal kernel}

A probability density function of the dispersal distances (dispersal kernel) from the core population was modelled. The data obtained in the field (trapped seed dispersal) were transformed to seed density per $\mathrm{m}^{2}$ by taking into account the area of the trap $\left(0.145 \mathrm{~m}^{2}\right.$, see in Bullock and Clarke 2000). The polynomic function of the density data was fitted to phenomenological models frequently observed by wind-mediated dispersal (Bullock et al. 2006): the negative exponential and the inverse power model (see Online Resource, Table OR1), and checked for goodness-of-fit $\left(\mathrm{r}^{2}\right)$ and standardized residuals.

\section{Species distribution models}

To assess the colonization potential of M. germanica, we used the method of species distribution modelling, where a habitat suitability matrix is calculated based on presence data and environmental predictor layers (Franklin 2009). Presence data for Switzerland of the German tamarisk were retrieved from the Swiss National data base Info Flora (www. infoflora.ch). Only coordinates with a precision of $\leq 100 \mathrm{~m}$ and collection dates starting from 1960 were used. Additionally, to avoid spatial autocorrelation, only one coordinate point per grid cell $(25 \times 25 \mathrm{~m})$ was kept (Guisan and Zimmermann 2000).

Environmental predictor layers for Switzerland with a resolution of $25 \times 25$ meters were chosen according to the species' ecology and previous findings for plant species (see Table 1 in; Breiner et al. 2015; Camathias et al. 2013). Climate, topographic and 
geological predictors are used as proxies to define the ecological niche of $M$. germanica along rivers in whole Switzerland. Layers were checked, projected and masked in ArcGIS (ESRI 2015). If predictor layers from an initial set of 20 predictors showed high collinearity ( $>0.75$, Pearson correlation test in raster package of $R$, R Core Team 2016), the more direct predictor was kept, resulting in 14 layers applied (Table 1). To account for the species' proximity to waterbodies, we clipped layers with a file created by using data on waterbodies in Switzerland. We added a buffer of $500 \mathrm{~m}$ around waterbodies to allow for sufficient space for dispersal by wind in flat and plain areas in Central Switzerland. A maximum entropy model was obtained using the software maxent (Phillips et al. 2006), by 10-fold crossvalidation and by sampling 10,000 background points. The corresponding habitat suitability map was used as an input for the package MigClim in R (Engler and Guisan 2009). Dispersal parameters were chosen according to the results from the extrapolation to $125 \mathrm{~m}$ distance of the polynomic model. The resulting dispersal kernel vector included 5 dispersal distances (corresponding to $25,50,75,100$ and $125 \mathrm{~m}$ ) with 5 probabilities $(0.97298,0.01173,0.00680,0.00479,0.00370)$. Initial maturity age for the German tamarisk is not exactly known. A related Myricaria species shows flowering after one year (M. laxiflora, Chen and Xie 2007), but we set the age to 3, as studies suggested maturity for M. germanica at 2-3 years (Bill et al. 1997; Lener et al. 2013). For increase in propagule production (compare to seed production variation between core population and the mature M. germanica shrub, see results below), we used a vector describing a $30 \%$

Table 1 Environmental predictor layers used for species distribution modelling of the German tamarisk in Switzerland

\begin{tabular}{|c|c|}
\hline Predictors & References \\
\hline \multicolumn{2}{|l|}{ Climatic predictors } \\
\hline Mean annual temperature & Zimmermann and Kienast (1999) \\
\hline Mean annual precipitation & Zimmermann and Kienast (1999) \\
\hline Mean annual number of summer precipitation days & Zimmermann and Kienast (1999) \\
\hline Annual global potential shortwave radiation & Algorithm following Kumar et al. (1997) \\
\hline $\begin{array}{l}\text { Mean annual number of frost days during the growing } \\
\text { season }\end{array}$ & Bolliger et al. (2000) \\
\hline Average site water balance & $\begin{array}{l}\text { Following Tarboton (1997), see Camathias et al. } \\
\text { (2013) }\end{array}$ \\
\hline \multicolumn{2}{|l|}{ Topographic predictors ${ }^{\mathrm{a}}$} \\
\hline Wetness index & $\begin{array}{l}\text { Following Tarboton (1997), see Camathias et al. } \\
\text { (2013) }\end{array}$ \\
\hline Topographic index & Camathias et al. (2013) \\
\hline Slope & Camathias et al. (2013) \\
\hline \multicolumn{2}{|l|}{ Geological predictors } \\
\hline $\begin{array}{l}\text { Calcareous content of the bedrock and surface } \\
\text { material }\end{array}$ & Lehmann et al. (2010) \\
\hline Soil permeability & Camathias et al. (2013) \\
\hline Water-holding capacity & Camathias et al. (2013) \\
\hline Hydrometric properties & Camathias et al. (2013) \\
\hline Stone content & Camathias et al. (2013) \\
\hline
\end{tabular}

\footnotetext{
a Based on DTM (25 m resolution)
} 
increase after age of maturity ( 3 years) to full age of maturity ( 5 years, see in Ellenberg 2010). Long-distance dispersal by water and rare extreme winds was included in the modelling, with a low probability (1\%) but over distances up to $10 \mathrm{~km}$ (see in Werth et al. 2014). We modelled the potential distribution of the species after 20 and 50 dispersal events (corresponding to 20 and 50 years), and compared occupied and colonized cells to initial presence points and absent cells of ten independent runs with paired two sample t-Tests.

\section{Results}

\section{Seed potential}

The results of the inflorescence phenology (Online Resource, Table OR2), of the estimates for buds per inflorescence (Online Resource, Table OR3, mature shrub: 41.9, mean core population: 39.1 ) and of the seeds per capsule (Online Resource, Table OR4, mature shrub: 103.1, core population: 103.7) were used to calculate the seed potential. The seed production of the total population of our study site at river Sense for the field season 2009 was estimated to be over 16.3 million seeds, with the majority being contributed by the mature M. germanica shrub (over 7.3 million seeds, Table 2). Seed production also varied

Table 2 Number of inflorescence and number of seeds of a mature $M$. germanica shrub and 22 individuals of the core population

\begin{tabular}{|c|c|c|}
\hline \#Plant & Number of inflorescences ${ }^{a}$ & Mean number of seeds \\
\hline Mature shrub & 1696 & $7,326,533$ \\
\hline \multicolumn{3}{|c|}{ Core population } \\
\hline 1 & 87 & 352,756 \\
\hline 2 & 72 & 291,936 \\
\hline 3 & 67 & 271,663 \\
\hline 4 & 89 & 360,866 \\
\hline 5 & 97 & 393,303 \\
\hline 6 & 76 & 308,155 \\
\hline 7 & 145 & 587,927 \\
\hline 8 & 121 & 490,615 \\
\hline 9 & 44 & 178,405 \\
\hline 10 & 68 & 275,718 \\
\hline 11 & 59 & 239,226 \\
\hline 12 & 138 & 559,544 \\
\hline 13 & 36 & 145,968 \\
\hline 14 & 78 & 316,264 \\
\hline 15 & 168 & 681,185 \\
\hline 16 & 233 & 944,738 \\
\hline 17 & 140 & 567,654 \\
\hline 18 & 10 & 40,547 \\
\hline 19 & 46 & 186,515 \\
\hline 20 & 24 & 97,312 \\
\hline 21 & 143 & 579,818 \\
\hline 22 & 185 & 750,114 \\
\hline
\end{tabular}

a Inflorescence counts of peak inflorescence day (09-07-2009) 
considerably between individuals of the core population (mean: $391,829 \pm 228,356$, see Table 2).

The germination experiment with single seeds in the lab showed that $78 \%$ of seeds of the total population germinated (Online Resource, Table OR 5). In the core population, $86.9 \%$ of the seeds germinated, while for the seeds obtained from the mature Myricaria shrub, only $67.7 \%$ germinated. These estimates were used to obtain an unbiased seed potential calculation: total population 12.7 million seeds, core population 7.8 million seeds, and mature shrub 4.9 million seeds.

\section{Wind-mediated dispersal distance}

A high amount of seeds were trapped directly below the mature shrub $(95,996)$ as well as the individuals of the core population $(469,78.3 \%$ of the total seeds trapped around the core population, see Fig. 1). With increasing distance from the core population, the amount of seeds trapped decreased considerably (see Fig. 1). We also observed a difference in the orientation of the seeds trapped: $49.2 \%$ were blown upstream (South), 15.4\% West, $26.2 \%$ East and 9.2\% North (downstream, see Fig. 1). These findings are confirmed by the direct visual observations of seed dispersal at various wind speed: the majority of seeds was

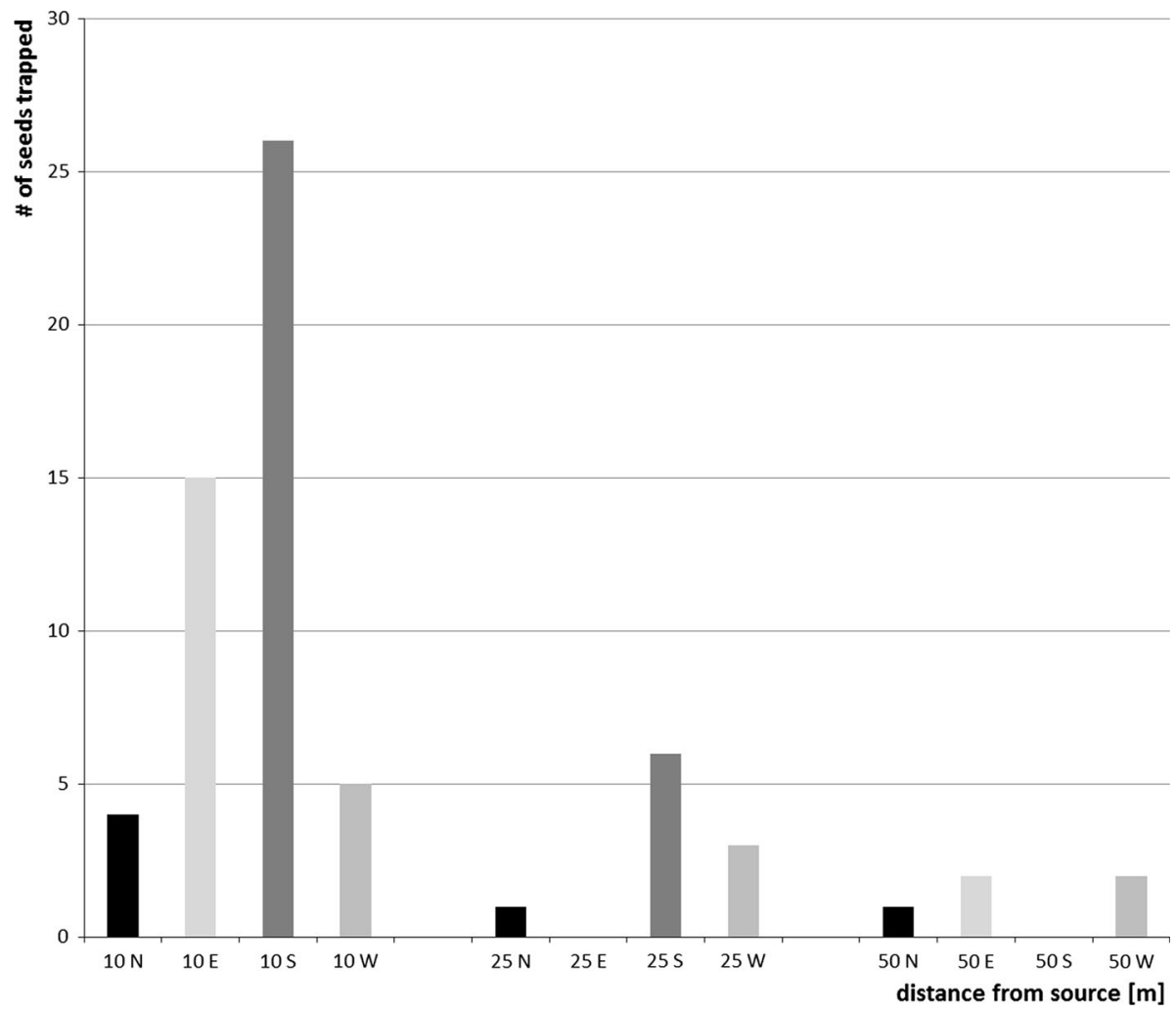

Fig. 1 Number of seeds trapped at three distances $(10,25,50 \mathrm{~m})$ from the core population and at all cardinals ( $N$ North, $E$ East, $S$ South, $W$ West). Seeds are mainly trapped close to the core population $(10 \mathrm{~m})$, and in upstream direction $(49.2 \%$, South) 
observed to disperse up to $10 \mathrm{~m}$ in upstream (South) direction (51.4\% for the mature shrub, $73.4 \%$ for the core population, see Online Resource, Figure OR1). The terminal velocity was measured as $0.16 \pm 0.01 \mathrm{~m} / \mathrm{sec}$ (see Online Resource, Table OR6). Direction of seed dispersal was mainly influenced by wind speed and wind direction, with highest wind speeds in South direction during early afternoon hours on sunny days, but longest observed seed dispersal towards Southeast and East (Online Resource, Figure OR1).

\section{Dispersal kernel}

The measured dispersal curve of the seeds trapped around the core population was contrasted to the predicted estimates of a polynomic function and two phenomenological models (Fig. 2, Online Resource Table OR7). The measured dispersal curve comprises a high number of seeds per $\mathrm{m}^{2}$ right next to the mother plant, while seed numbers decrease thereafter resulting in a long tail of the curve. The polynomic model overestimates seed density at the source and at $25 \mathrm{~m}$ distance, but fits well at $50 \mathrm{~m}$ distance. The negative exponential model strongly underestimates seed density at the source, but results in overestimations at 10 and $25 \mathrm{~m}$, and does not show a long tail for extrapolations to $125 \mathrm{~m}$. Contrary to that, the inverse power model fits very well to estimates for the source and $10 \mathrm{~m}$ distance, but strongly underestimates seed density at increasing distances from the core population. No more seeds were estimated at $50 \mathrm{~m}$ distance from the core population by the inverse power model, and similarly no more seeds were anticipated at $100 \mathrm{~m}$ distance by the negative exponential model. These rapid decreases in seed density estimates prevent the modelling of long-distance dispersal. Standardized residuals were checked and within boundaries of -2 to +2 for the polynomic and the negative power model, but not for the inverse power model. Since the polynomic model shows a long tail and the best goodness-of-fit $\left(r^{2}=0.9858\right.$, compared to $r^{2}=0.8167$ for the negative exponential), this model was used to calculate the dispersal kernel in the distribution model.

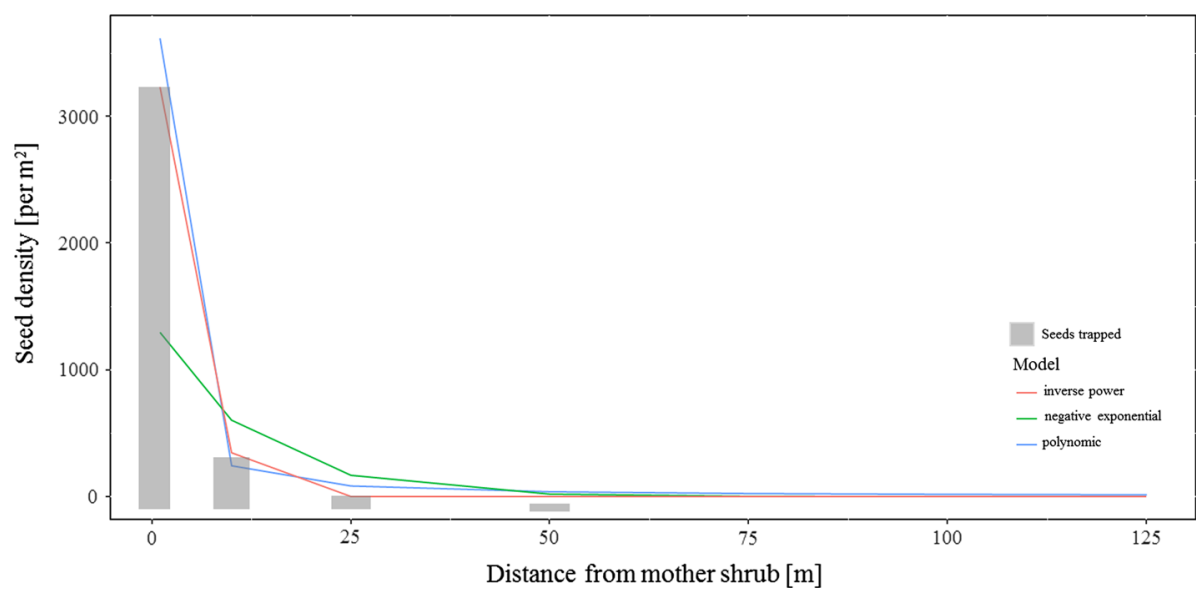

Fig. 2 Dispersal kernel of the trapped seed density, the corresponding polynomic function and the predicted density distribution by two phenomenological models (negative exponential and inverse power). The polynomic function showed the highest goodness-of-fit to the trapped seed density data 


\section{Species distribution models}

To identify suitable habitats and to predict dispersal of $M$. germanica individuals from current populations to new habitat, we modelled the distribution of the species in Switzerland. We used 298 data points and 14 predictor layers to estimate a model and to obtain a habitat suitability matrix. AUC values for model verification showed models with a good prediction accuracy (average AUC: 0.963, compare to Manel et al. 2001). The habitat suitability map revealed few habitats with high suitability (Fig. 3). The potential distribution after wind dispersal from the current species presence points revealed only few newly occupied habitats after 20 and 50 years (see Fig. 4), with a majority of cells remaining unoccupied (over 27 million cells for both 20 and 50 dispersal events, compared to 17,707.2 cells and 49,769.9 cells occupied respectively). Nevertheless, difference between initially occupied cells and cells colonized at the end of the simulation were significant (20 dispersal events: $\mathrm{t}-$ Test, $\mathrm{t}=-596.1, \mathrm{p}<0.001 ; 50$ dispersal events: $\mathrm{t}-$ Test, $\mathrm{t}=-272.97, \mathrm{p}<0.001$ ).

\section{Discussion}

\section{Seed potential}

The counting of inflorescence and seeds of the mature M. germanica shrub and of individuals of the core population revealed a high seed potential of the species. Given that our

\section{Legend}

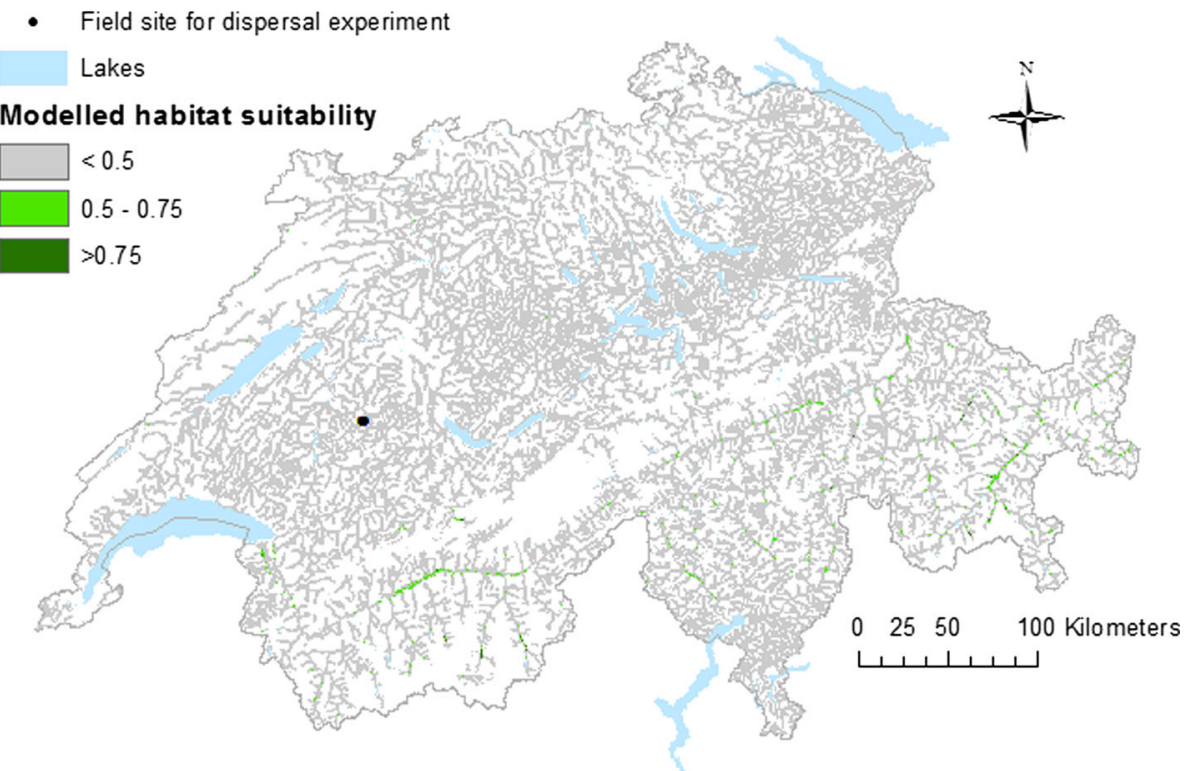

Fig. 3 Habitat suitability map of M. germanica in Switzerland based on 14 environmental predictor layers, clipped with a $500 \mathrm{~m}$ buffer zone around waterbodies. The site of the dispersal experiment is shown as a black dot. Habitat with a modelled high suitability is shown in dark green, while intermediate and low suitability is shown in light green and grey. Only few habitat along the river catchments in Southern Switzerland (Rhone, Rhein, Inn, from left to right) display regions with high suitability based on modelling 


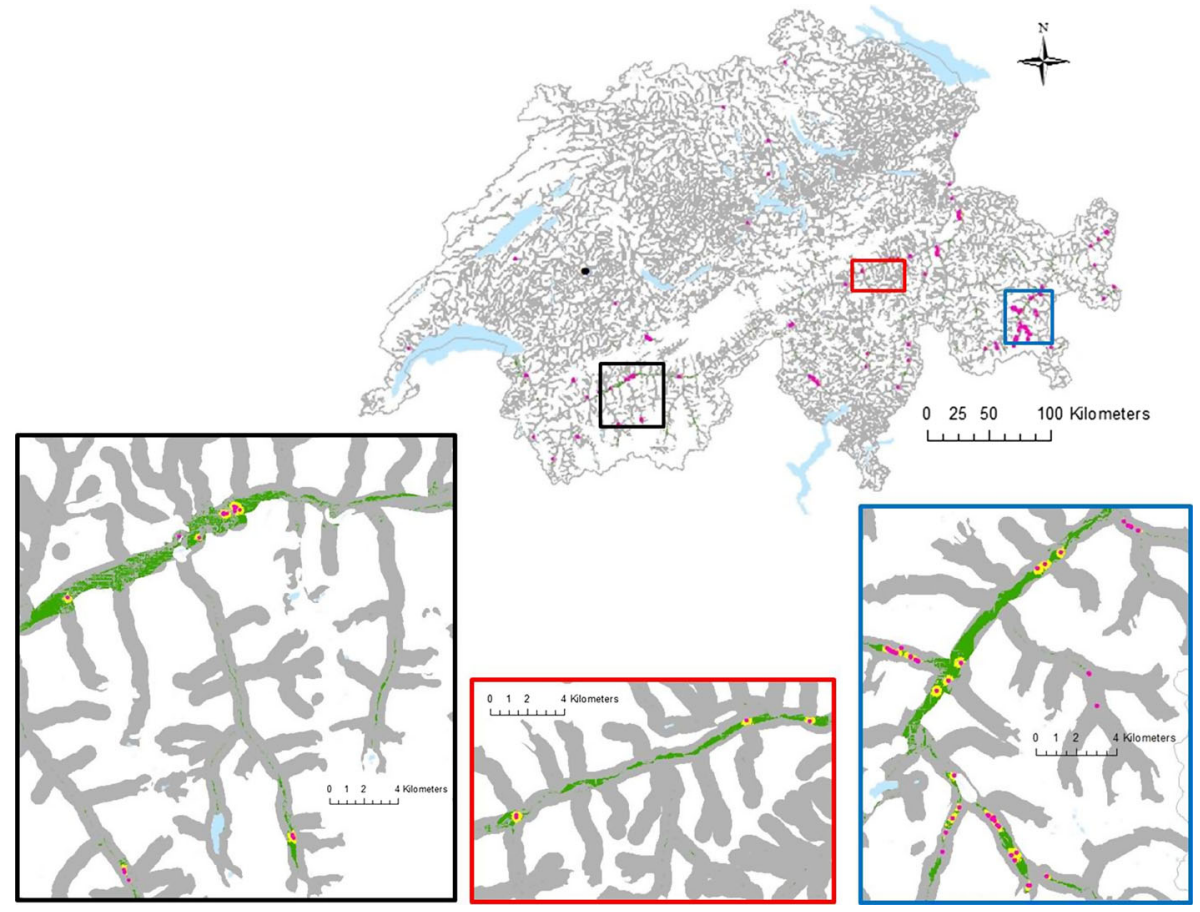

Fig. 4 Modelled potential distribution of the German tamarisk after wind-mediated dispersal for 20 years. Coloured cells represent newly colonized (yellow) or suitable, but not yet colonized (green) habitats during dispersal events. Grey colour indicates non-colonized and non-suitable cells. Source populations are shown as pink dots, while the site of the dispersal experiment is indicated as a black dot. Modelled potential distribution in the catchments of river Rhone (black frame), Rhein (red frame) and Inn (blue frame) are shown in detail. Limited wind-mediated dispersal abilities of the German tamarisk prevent major population expansions despite modelled habitat suitability

field work on inflorescence phenology included the peak of seed production, we are confident that our study is a representative sample of the seed potential of the German tamarisk in Switzerland. Seed production has been previously reported to be 12,000-15,000 diaspores/individual (Kammerer 2003), 10,000-200,000 seeds/individual (Bill et al. 1997) or averages of 22,000 to 3,306,000 seeds/individual, depending on the age of the German tamarisk (Lener et al. 2013). Similarly, the seed counts of young individuals of the core population display a high range of total seeds, while the seed production of the mature shrub exceeded the values found by previous studies. High seed production is considered to be an ecological adaptation of plants with low seedling recruitment (Parolin 2001), and has been found in other Myricaria species (Myricaria laxiflora, Chen and Xie 2007). Despite high seed production, previous genetic analyses on the same population have shown no genetic diversity at multilocus genotypes for the mature German tamarisk and the core population (Werth et al. 2014). Given the lack of genetic diversity and the much higher seed production of the single mature shrub, it is likely to be the source of the population at the sampling site, and to be the main contributor to the survival of the species in the sampling area at the river Sense. The high seed potential as well as the presence of young and mature shrubs at the study site indicate that seed production and germination are not limiting factors for the species persistence. 


\section{Wind-mediated dispersal}

Despite the high seed production, only few wind-dispersed seeds were recovered in the traps. Additionally, the majority of seeds were trapped beneath the mother shrubs both for the mature shrub and the core population, resulting in a leptokurtic distribution (see Grivet et al. 2005). These findings are similar to another study on the German tamarisk in Austria (Lener 2011), to results from another Myricaria species (M. laxiflora, Chen and Xie 2007), and from another tree species (Pinus halepensis, Nathan et al. 2000). As germination is usually prevented next to the mother shrub due to the lack of soil humidity and light, these seeds might not contribute to the species' survival (Kammerer 2003).

Direct observation and trapping of seeds revealed wind dispersal of seeds up to $50 \mathrm{~m}$ from the mother shrub. While another trapping experiment recorded distances up to $90 \mathrm{~m}$ in one direction from the mother shrub (Lener 2011), flight observations of $M$. germanica seeds were reported to be up to $100 \mathrm{~m}$ (Bill et al. 1997). Given the outline of the sampling site, longer distances than $50 \mathrm{~m}$ could not be measured for the core population in our study. Due to the strong decrease of number of seeds trapped at 10 and $25 \mathrm{~m}$ already, we would not expect many seeds over $100 \mathrm{~m}$ distance from the core population (see also in Lener 2011). Comparative analyses for various shrub species have shown that wind dispersal involves much shorter distances than e.g. animal- or water-mediated dispersal (Clark et al. 2005; Nathan 2006; Nathan et al. 2008; Nilsson et al. 2010).

For the conservation of a species in a fragmented landscape, both the distance and the direction of dispersal are important (Driscoll et al. 2014; Ruxton and Schaefer 2012). Our measurements of the direction of the wind dispersal clearly revealed a majority of seeds in the South of the core population, in the opposite direction of the river flow. Similarly, other studies report the importance of upstream dispersal for riparian species (for a overview see Wubs et al. 2016). In our study, upstream dispersal is explained by the prevailing katabatic winds during early afternoon hours, when seed capsules open and release seeds, being the main factor influencing the direction of dispersal (Bullock et al. 2006). Wind speed was not a major factor influencing dispersal distance, with longest distances being observed at low wind speeds. Additionally, the terminal velocity measured in the lab does not correspond to observed wind dispersal distances and cannot substitute direct observations in the field. Thus, if main wind directions are similar over several flowering seasons, the knowledge of the dispersal direction is an important factor for conservation management and habitat protection of the population on the study site.

The dispersal kernel for the wind dispersal of the core population of our study site is most similar to a simple polynomic curve. Due to its few parameters and strong decrease, the polynomic model adequately follows the dispersal curve of intermediate distances from the mother shrub, and includes a long flat tail. Similarly, models for plants with similar terminal velocity and height as estimated for our study species, a high wind dispersal potential has been suggested (Tackenberg 2003). Nevertheless, long-distance seed dispersal by wind is more likely a rare, extreme event, in which several factors are involved (Nathan 2006; Nathan et al. 2000; Tackenberg 2003). Extremes in horizontal or vertical wind speeds may be important to disperse a small number of seeds over long-distances (Bullock and Clarke 2000), as our results on observed seed flights confirm. But turbulences as well as weather conditions have to be taken into account for modelling long-distance dispersal (Tackenberg 2003). Moreover, mainly mechanistic models and genetic markers are considered to be ideal to estimate long-distance dispersal (Bullock et al. 2006; Clobert et al. 2012). Future studies need to address long-distance dispersal and the corresponding 
dispersal kernel for $M$. germanica, and additionally need to take into account other dispersal mechanisms (e.g. hydrochory, Nilsson et al. 2010). Still, wind-mediated shortdistance dispersal might be sufficient for the persistence of a species, but is highly dependent on habitat fragmentation.

\section{Colonization potential}

Our trapping results suggest that Myricaria germanica is an intermediate disperser, with high seed production and average dispersal distances by wind-mediated dispersal for a plant species. Nevertheless, the potential distribution of the German tamarisk after 20 and 50 years shows newly colonized habitat along the rivers in Switzerland, which is in accordance with the pioneer characteristics of the species (Ellenberg 2010). Maximum entropy modelling of Switzerland has revealed only regions along three main river catchments (Rhone, Rhein, Inn) displaying habitat with high probability, and dispersal remained limited along these catchments. This is mainly influenced by low wind dispersal probabilities to distances over $50 \mathrm{~m}$ and rare long-distance dispersal. Similarly, it has been shown for other species, that the dispersal scenario highly influences the predicted distribution of the species (Engler et al. 2009).

The model reveals that current low numbers of source populations in Switzerland and the modelled habitat suitability are not likely to allow for a major spread of the species. Nevertheless, modelling based on climate predictors for the invasive tamarisk species (Tamarix chinensis, T. ramosissima), and native poplar and willow species under climate change scenarios identified tamarisks as the major beneficiary of climate change with most predicted suitable habitat in North America (Ikeda et al. 2014). Contrary to that, our model with climate as well as topographic and geological predictors is less optimistic for a spread throughout Switzerland even after 50 years of dispersal, but future climate scenarios would need to be included in a future study. Riparian areas show high differences in habitat composition from adjacent landscapes (Catford and Jansson 2014; Sabo et al. 2005) and buffer water temperature (Barton et al. 1985), resulting in different microclimatic conditions for riparian habitats. Therefore, we are confident that the addition of non-climate predictors enhances the suitability of the model (see also Kudrnovsky 2013).

The successful spread of $M$. germanica is highly dependent on the formation of gravel banks (Gostner et al. in press), which are not included in the ecological niche definition in our model, due to lack of data. Future studies need to implement additional habitat key characteristics (e.g. estimates of sediment deposition and erosion) as well as predictors describing river dynamics (e.g. channel dynamics, see Richards et al. 2002). Moreover, the interaction between barriers to dispersal and colonization as well as the influence of barriers along river on habitat suitability has to be investigated (Sitzia et al. 2016).

Despite reflecting probabilistic modelling on habitat conditions and not taking into account microhabitat conditions and seed potential per se, the modelled limited spread of the German tamarisk in Switzerland is in correspondence with processes leading to reduced colonization potential in the real world. Short-distance dispersal of the majority of the seeds produced allow seeds to reach habitat with similar environmental conditions as the habitat of the mother shrub. Still, there is competition for space, light and nutrients with the mother shrub (see Ronce 2007). Wind dispersed seeds travelling longer distances from the mother shrub can land outside limited suitable habitat areas like gravel banks. Additionally, the small seeds of the German tamarisk do not have any storage tissue or nutrient reservoirs, and are therefore dependent on landing directly on the surface of the substrate, as they cannot grow through it (Bill et al. 1997). These limitations require that seeds land 
on suitable sites shortly after release (Bill et al. 1997), which is well represented in the applied modelling approach.

Although the dispersal model applied takes into account limiting factors such as differences in propagule production and initial maturity age, it might still overestimate the spread of the species in the real world: e.g. sediment turnover and flooding as well as subsequent low water levels might result in additional loss of seedlings or suitable habitat (Naiman et al. 2005). Low juvenile survival rate (Bill 2000) as well as competition and biotic interactions between riparian species were not considered in this model (Ellenberg 2010). The mature shrub in the field experiment was surrounded by Salix ssp. shrubs, which likely prevented dispersal and germination of seeds in proximity to these willows. Therefore, future studies need to address competition as well as biotic interactions of riparian plant communities (e.g. see Ovaskainen et al. 2016; Pollock et al. 2014).

\section{Management implications}

Modelling of dispersal by wind indicates, that the species is not likely to considerably expand from the current source populations, as it is not likely to reach all potentially suitable habitat within time spans of 20 and 50 years. In fragmented landscape, a sessile plant species which can spread mainly over short distances by wind dispersal is under threat to go extinct, especially with limited source populations as it is the case for the German tamarisk (Endress 1975). Therefore, the species currently seems to be trapped in an extinction vortex of the type $\mathrm{D}$, which results in a patchy population distribution (Gilpin and Soule 1986). Still, its regeneration potential after sediment turnover might allow the species to persist in limited areas (Ellenberg 2010), but seed dispersal is needed for successful colonization of new habitat and to ensure gene flow (Stocklin et al. 2004).

Long-range seed dispersal of the German tamarisk is mediated by extreme wind or water (hydrochory, Nilsson et al. 1991), but is subject to limitations due to barriers along river networks (Werth et al. 2014). Thus lack of connectivity between riparian areas and fragmented river habitats might additionally inhibit the successful spread of the species (Leyer 2006; Nilsson et al. 2010). To allow for the conservation of the species in Switzerland and its escape from the extinction vortex it is currently trapped in, populations and their natural habitat should be protected to prevent additional decrease of populations (Kudrnovsky and Stöhr 2013). Additional management measures must be taken to allow for the formation of new suitable riparian habitat in areas with high probability of habitat suitability. For example, river bed widening allowing for the formation of new gravel banks with high turnover rate would increase habitat availability (Gostner et al. in press). Connectivity of contemporary source populations to new habitat must be ensured by taking into account dispersal distance of the German tamarisk, as measured in our study, to allow the species to overcome its current bottleneck situation (compare to Werth et al. 2014). If potentially suitable habitats can no longer be reached by natural source populations, conservation transplantation has to be considered as a conservation strategy (Fiedler and Kareiva 1998). Still, sediment composition in transplantation areas has to be monitored, as it can influence transplant growth (Mörz 2013). The results of our study can be used for conservation planning of designated river catchments by identifying habitats with high suitability for conservation transplantation or restoration, and by providing knowledge on dispersal distance. This allows adjusting conservation goals for fragmented landscape and limited space availability. 
Acknowledgements We thank two anonymous reviewers for their suggestions on a previous version of the manuscript. We are grateful to Barbara Krummenacher and Silke Werth for help with field work, and to Lyudmyla Dymytrova, Klaus Ecker and Martin Hägeli for help with ArcGIS layers. Funding was provided by the Swiss Federal Office for the Environment for the project "habitat and sediment dynamics".

\section{References}

Barton DR, Taylor WD, Barton D, Taylor W, Biette RM (1985) Dimensions of riparian buffer strips required to maintain trout habitat in southern Ontario streams. North Am J Fish Manag 5:364-378

Bill H-C (2000) Besiedlungsdynamik und Populationsbiologie charakteristischer Pionierpflanzenarten nordalpiner Wildflüsse. PhD, Philipps-Universität Marburg

Bill H-C, Spahn P, Reich M, Plachter H (1997) Bestandesveränderungen und Besiedlungsdynamik der Deutschen Tamariske, Myricaria germanica Desv., an der Oberen Isar (Bayern) vol 6

Bolliger J, Kienast F, Zimmermann NE (2000) Risks of global warming on montane and subalpine forests in Switzerland? A modeling study. Reg Environ Change Nat Soc Asp 1:99-111

Bornand C et al (2016) Rote Liste Gefässpflanzen-Gefährdete Arten der Schweiz. Umwelt-Vollzug Nr. 1621. Bundesamt für Umwelt, Bern

Breiner F, Guisan A, Bergamini A, Nobis M, Anderson B (2015) Overcoming limitations of modelling rare species by using ensembles of small models. Methods Ecol Evol 6:1210-1218

Brook BW, Sodhi NS, Bradshaw CJA (2008) Synergies among extinction drivers under global change. Trends Ecol Evol 23:453-460

Bullock JM, Clarke RT (2000) Long distance seed dispersal by wind: measuring and modelling the tail of the curve. Oecologia 124:506-521

Bullock J, Shea K, Skarpaas O (2006) Measuring plant dispersal: an introduction to field methods and experimental design. Plant Ecol 186:217-234

Camathias L, Bergamini A, Kuechler M, Stofer S, Baltensweiler A, Küchler M, Rocchini D (2013) Highresolution remote sensing data improves models of species richness. Appl Veg Sci 16:539-551

Catford J, Jansson R (2014) Drowned, buried and carried away: effects of plant traits on the distribution of native and alien species in riparian ecosystems. New Phytol 204:19-36

Chen F-Q, Xie Z-Q (2007) Reproductive allocation, seed dispersal and germination of Myricaria laxiflora, an endangered species in the Three Gorges Reservoir area. Plant Ecol 191:67-75

Clark CJ, Poulsen JR, Bolker BM, Connor EF, Parker VT (2005) Comparative seed shadows of bird-, monkey-, and wind-dispersed trees. Ecology 86:2684-2694

Clobert J, Baguette M, Benton TG, Bullock JM (2012) Dispersal ecology and evolution. Oxford University Press, Oxford

Driscoll D, Banks S, Barton P, Lindenmayer D, Smith A (2013) Conceptual domain of the matrix in fragmented landscapes. Trends Ecol Evol 28:605-613

Driscoll D et al (2014) The trajectory of dispersal research in conservation biology. Systematic review. PLoS ONE 9:e95053-e95053

Ellenberg H (2010) Vegetation Mitteleuropas mit den Alpen in ökologischer, dynamischer und historischer Sicht. UTB für Wissenschaft: Uni-Taschenbücher, 6., vollst. neu bearb. und stark erw. Aufl. edn. Ulmer, Stuttgart

Endress P (1975) Der Verbreitungsrückgang von Myricaria germanica Desv. und Typha minima Hoppe auf der Alpennordseite Graubündens. Vierteljahrsschrift der Naturforschenden Gesellschaft in Zürich 120:1-14

Engler R, Guisan A (2009) MigClim: predicting plant distribution and dispersal in a changing climate. Divers Distrib 15:590-601

Engler R et al (2009) Predicting future distributions of mountain plants under climate change: does dispersal capacity matter? Ecography 32:34-45

ESRI (2015) ArcGIS Desktop: Release 10.2.2. Environmental Systems Research Institute, CA

Fiedler PL, Kareiva PM (eds) (1998) Conservation biology for the coming decade, 2nd edn. Chapman \& Hall, New York

Franklin J (2009) Mapping species distributions: spatial inference and prediction. Cambridge University Press, Cambridge

Gilpin ME, Soulé ME (1986) Minimum viable populations: processes of species extinction. In: Soulé ME (ed) Conservation biology: the science of scarcity and diversity. Sinauer, Sunderland, pp 19-34

Gostner W, Paternolli M, Schleiss AJ, Scheidegger C, Werth S (in press) Gravel bar inundation frequency: an important parameter for understanding riparian corridor dynamics. Aquatic Sci 
Greene DF, Calogeropoulos E (2002) Measuring and modelling seed dispersal of terrestrial plants. In: Bullock JM, Kenward RE, Hails RS (eds) Dispersal ecology: The 42nd symposium of the British Ecological Society held at the University of Reading; 2-5 April 2001. Blackwell Science Ltd., Malden, pp 3-23

Grivet D, Smouse P, Sork V (2005) A novel approach to an old problem: tracking dispersed seeds. Mol Ecol $14: 3585-3595$

Guisan A, Zimmermann N (2000) Predictive habitat distribution models in ecology. Ecol Model 135:147-186

Ikeda D, Grady K, Shuster S, Whitham T, Boldgiv B (2014) Incorporating climate change and exotic species into forecasts of riparian forest distribution. PLoS ONE 9:e107037

Jansson R, Nilsson C, Renöfält B (2000) Fragmentation of riparian floras in rivers with multiple dams. Ecology 81:899-903

Kammerer H (2003) Artenschutzprojekt Deutsche Tamariske-Möglichkeiten und Aussichten einer Wiederbesiedlung von Myricaria germanica im Gesäuse. Nationalpark Gesäuse GmbH

Kolly D (2007) Myricaria germanica Populationsentwicklung zwischen 1975 und 2007 in zwei Testgebieten des Kantons Graubünden. University of Bern

Kudrnovsky H (2013) Alpine rivers and their ligneous vegetation with Myricaria germanica and riverine landscape diversity in the Eastern Alps: proposing the Isel river system for the Natura 2000 network. Ecomont 5:5-18

Kudrnovsky H, Stöhr O (2013) Myricaria germanica Desv. historisch und aktuell in Österreich: ein dramatischer Rückgang einer Indikatorart von europäischem Interesse. STAPFIA: reports 99:13-34

Kumar L, Skidmore A, Knowles E (1997) Modelling topographic variation in solar radiation in a GIS environment. Int J Geograph Inform Sci 11:475-497

Lehmann A, Allenbach K, Maggini R, Richard J-P, Jacquet J-M, Dao H (2010) Swiss environmental domains: a new spatial framework for reporting on the environment. Federal Office for the Environment FOEN, Environmental studies no 1024, Bern

Lener FP (2011) Etablierung und Entwicklung der Deutschen Tamariske (Myricaria germanica) an der oberen Drau in Kärnten. Master Thesis, University of Vienna

Lener FP, Egger G, Karrer G (2013) Sprossaufbau und Entwicklung der Deutschen Tamariske (Myricaria germanica) an der Oberen Drau (Kärnten, Österreich). Carinthia II 203:515-552

Levey DJ, Silva WR, Galetti M (2002) Seed dispersal and frugivory: ecology, evolution and conservation. Third International Symposium-Workshop on Frugivores and Seed Dispersal, São Pedro, pp 16-511

Leyer I (2006) Dispersal, diversity and distribution patterns in pioneer vegetation: the role of river-floodplain connectivity. J Veg Sci 17:407-416

Lytle D, Poff NL (2004) Adaptation to natural flow regimes. Trends Ecol Evol 19:94-100

Manel S, Williams HC, Ormerod SJ (2001) Evaluating presence-absence models in ecology: the need to account for prevalence. J Appl Ecol 38:921-931

McGeoch M, Latombe G (2016) Characterizing common and range expanding species. J Biogeogr 43:217-228

Mörz S (2013) Einfluss des Keimsubstrats auf die Etablierung und das Konkurrenzverhalten von auentypischen Pflanzenarten sowie invasiven Pflanzenarten. Hochschule Weihenstephan-Triesdorf

Müller N, Scharm S (2001) The importance of seed rain and seed bank for the recolonisation of gravel bars in alpine rivers. In: Okuda $\mathrm{S}$ (ed) Studies on the vegetation of alluvial plants. Yokohama National University, Yokohama, pp 127-140

Naiman RJ, Décamps N, McClain ME (2005) Riparia: Ecology, conservation, and management of streamside communities. Elsevier, New York

Nathan R (2001) The challenges of studying dispersal. Trends Ecol Evol 16:481-483

Nathan R (2006) Long-distance dispersal of plants. Science 313:786-788

Nathan R, Safriel U, Noy Meir I, Schiller G (2000) Spatiotemporal variation in seed dispersal and recruitment near and far from Pinus halepensis trees. Ecology 81:2156-2169

Nathan R, Schurr F, Spiegel O, Steinitz O, Trakhtenbrot A, Tsoar A (2008) Mechanisms of long-distance seed dispersal. Trends Ecol Evol 23:638-647

Nilsson C, Gardfjell M, Grelsson G (1991) Importance of hydrochory in structuring plant-communities along rivers. Can J Bot 69:2631-2633

Nilsson C, Brown R, Jansson R, Merritt D (2010) The role of hydrochory in structuring riparian and wetland vegetation. Biol Rev 85:837-858

Ovaskainen O, Roy D, Fox R, Anderson B, Orme D (2016) Uncovering hidden spatial structure in species communities with spatially explicit joint species distribution models. Methods Ecol Evol 7:428-436

Parolin P (2001) Morphological and physiological adjustments to waterlogging and drought in seedlings of Amazonian floodplain trees. Oecologia 128:326-335 
Phillips S, Anderson R, Schapire R (2006) Maximum entropy modeling of species geographic distributions. Ecol Model 190:231-259

Pollock LJ et al (2014) Understanding co-occurrence by modelling species simultaneously with a Joint Species Distribution Model (JSDM). Methods Ecol Evol 5:397-406

Pullin A et al (2009) Conservation focus on europe: major conservation policy issues that need to be informed by conservation science. Conserv Biol 23:818-824

R Core Team (2016) R: a language and environment for statistical computing. R Foundation for Statistical Computing. http://www.R-project.org/

Richards K, Brasington J, Hughes F (2002) Geomorphic dynamics of floodplains: ecological implications and a potential modelling strategy. Freshw Biol 47:559-579

Richardson D, Holmes P, Esler K, Galatowitsch S, Stromberg J (2007) Riparian vegetation: degradation, alien plant invasions, and restoration prospects. Divers Distrib 13:126-139

Ronce O (2007) How does it feel to be like a rolling stone? Ten questions about dispersal evolution. Annu Rev Ecol Evol Syst 38:231-253

Ruxton G, Schaefer HM (2012) The conservation physiology of seed dispersal. Philos Trans R Soc Biol Sci $367: 1708-1718$

Sabo J et al (2005) Riparian zones increase regional species richness by harbouring different, not more, species. Ecology 86:56-62

Sitzia T, Michielon B, Iacopino S, Kotze DJ (2016) Population dynamics of the endangered shrub Myricaria germanica in a regulated alpine river is influenced by active channel width and distance to check dams. Ecol Eng 95:828-838

Stocklin J, Stöcklin J, Winkler E (2004) Optimum reproduction and dispersal strategies of a clonal plant in a metapopulation: a simulation study with Hieracium pilosella. Evol Ecol 18:563-584

Sweeney B, Newbold JD (2014) Streamside forest buffer width needed to protect stream water quality, habitat, and organisms: a literature review. J Am Water Resour Assoc 50:560-584

Swift T, Hannon S (2010) Critical thresholds associated with habitat loss: a review of the concepts, evidence, and applications. Biol Rev 85:35-53

Tackenberg O (2003) Modeling long-distance dispersal of plant diaspores by wind. Ecol Monogr 73:173-189

Tarboton DG (1997) A new method for the determination of flow directions and upslope areas in grid digital elevation models. Water Resour Res 33(2):309-319

Werth S, Scheidegger C, Vendramin G (2014) Gene flow within and between catchments in the threatened riparian plant Myricaria germanica. PLoS ONE 9:e99400

Willson MF (1993) Dispersal mode, seed shadows, and colonization patterns. Vegetatio 107-108:261-280

Wubs ERJ et al (2016) Going against the flow: a case for upstream dispersal and detection of uncommon dispersal events. Freshw Biol 61:580-595

Zimmermann N, Kienast F (1999) Predictive mapping of alpine grasslands in Switzerland: species versus community approach. J Veg Sci 10:469-482 